
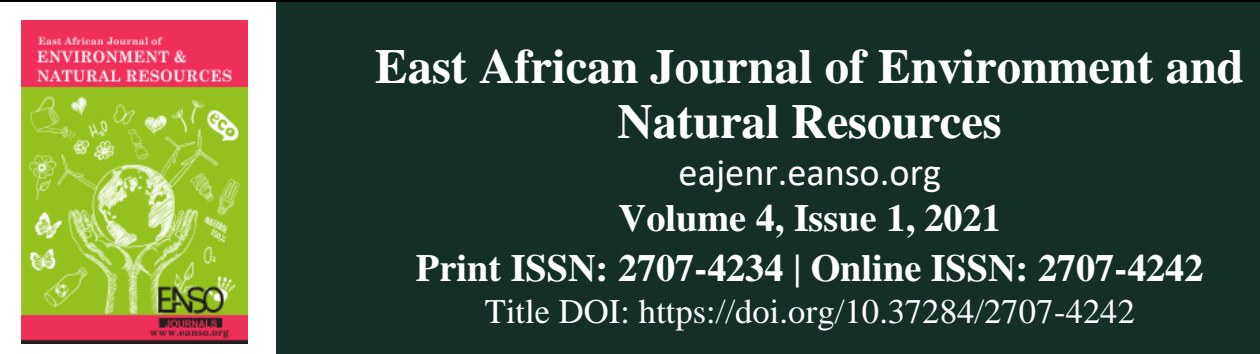

Original Article

\title{
Assessing the Inter-Relationship between Rural Population Migration and Environmental Change in the Dano Watershed, Burkina Faso.
}

\author{
Binta Dansoko ${ }^{1} \&$ Dr. Souleymane Sidi Traore, $P h D^{2 *}$ \\ ${ }^{1}$ Netherlands Development Organisation, Ségou, Mali \& Department of Geography, Université de Lomé. \\ ${ }^{2}$ Department of Geography, Faculty of History and Geography, University of Social Sciences and Management of Bamako. \\ *Correspondence ORCID ID: https://orcid.org/0000-0002-8373-7205; email: sstraore@ yahoo.fr.
}

Article DOI: https://doi.org/10.37284/eajenr.4.1.517

\section{Date Published: ABSTRACT}

27 December 2021 The study analyses the Land Use and Land Cover (LULC) dynamics as an important environmental factor and links it to migration trends towards

Keywords: the study area. The work uses data collected across two (2) villages, both located in the Dano watershed. Three sets of 30-m Landsat images were

Environmental Change,

Migration,

Land Use,

Land Cover Change,

Dano Watershed,

Burkina Faso. 2014. Cumulatively focus group discussion and household interview were employed for socio-economic data collection. Census data for the periods 1987, 1996 and 2006 were also collected from the national census reports. LULC analysis revealed that vegetation area was progressively converted into croplands with an annual rate of $0.92 \%$ during the period of study. Pearson correlation analysis between population and cropland on one hand and population and vegetation on the second hand revealed a high positive correlation between population size and cropland $(r=0.99)$, while there was a high negative correlation between population size and vegetation $(r=0.96)$. The survey of 180 farmers revealed a diversity of questions about environmental change on their livelihood. Most $78 \%$ of farmers believe that deforestation is the main driver of environmental change as a result of the decrease of rainfall and strong wind. Many strategies are used by local communities as a response to environmental changes and migration is seen by $31 \%$ of the respondents as a common strategy used by the affected communities. These results from the study showed that migration is one of the major local responses to environmental change.

79 | This work is licensed under a Creative Commons Attribution 4.0 International License. 


\section{APA CITATION}

Dansoko, B. \& Traore, S. S. (2021). Assessing the Inter-Relationship between Rural Population Migration and Environmental Change in the Dano Watershed, Burkina Faso. East African Journal of Environment and Natural Resources, 4(1), 79-87. https://doi.org/10.37284/eajenr .4.1.517

\section{CHICAGO CITATION}

Dansoko, Binta \& Souleymane Sidi Traore. 2021. "Assessing the Inter-Relationship between Rural Population Migration and Environmental Change in the Dano Watershed, Burkina Faso". East African Journal of Environment and Natural Resources 4 (1), 79-87. https://doi.org/10.37284/eajenr.4.1.517.

\section{HARVARD CITATION}

Dansoko, B. Traore, S. S. (2021) "Assessing the Inter-Relationship between Rural Population Migration and Environmental Change in the Dano Watershed, Burkina Faso", East African Journal of Environment and Natural Resources, 4(1), pp. $79-87$. doi: 10.37284/eajenr.4.1.517.

\section{IEEE CITATION}

B. Dansoko \& S. S. Traore, "Assessing the Inter-Relationship between Rural Population Migration and Environmental Change in the Dano Watershed, Burkina Faso", EAJENR, vol. 4, no. 1, pp. 79-87, Dec 2021.

\section{MLA CITATION}

Dansoko, Binta \& Souleymane Sidi Traore. "Assessing the Inter-Relationship between Rural Population Migration and Environmental Change in the Dano Watershed, Burkina Faso". East African Journal of Environment and Natural Resources, Vol. 4, no. 1, Dec 2021, pp. 79-87, doi:10.37284/eajenr.4.1.517.

\section{INTRODUCTION}

Demographic dynamics in Burkina Faso, like other West African countries, have been characterised by population movements since pre-colonial times (Sow et al., 2014, Abdul-korah, 2008). The high population density has culminated in pressure on land, over-exploitation of scarce natural resources and environmental degradation (Sow et al., 2014, IFAD, 2011). Land use and land cover (LULC) changes are closely interconnected in multiple and bidirectional ways to changes in local livelihoods and the provision of ecosystem services (carbon, biodiversity, water, etc.) ( Vliet et al., 2013, Warner, 2011). The environmental change includes drought that has affected agricultural and livestock productivity across the Sahel (Sanfo et al., 2014, Sanfo et al., 2015, Zoungrana et al., 2015, Masih et al., 2014). In the Sahel region, Burkina Faso in particular, rapid population growth coupled with rural-rural migration have been highlighted as the main driver of LULC (Ouedraogo et al., 2009).

There are a rapidly growing number of studies on various environmental change-related issues, especially during the last decade. Most of them have been renewed interest in the use of remote sensing and GIS for LULC assessment (Ouedraogo et al., 2009, Ouedraogo et al., 2010, Geest et al., 2010). However, the strategy to respond to the environmental change "migration" as livelihood diversification has received less attention. However, its ongoing and potential contribution to society is still underestimated. It is against this background that this research aims at assessing rural population response to environmental change in the Dano Watershed. The research site has been selected because of several reasons: i) characterised by a high population dynamic with pressure on available land; ii) high rainfall fluctuation and the area faced from several extreme weather in the recent decade; and it is expected to be affected by future like in many West African countries; iii) good records of existing long-term historical socio-economic data are available. Since the area is among the fertile zone "breadbasket" in the country.

\section{MATERIAL AND METHOD}

\section{Study Area}

This study was carried out in the Dano watershed located within two municipalities (Koti and Dano) South-West of Burkina Faso. The watershed is composed of seventeen (17) villages within two provinces, namely Ioba and Tuy. Its area covers around $582.42 \mathrm{~km}^{2}$ (Figure 1). Dano city is crossed by a big backwater "Gbataziè", which drains rainwater from Southern to North. The vegetation is dominated by grass and scattered trees. However, the distribution of vegetation cover depends largely on the amount of annual rainfall and its duration. 
The area is under a tropical climate; the annual rainfall is around $900 \mathrm{~mm}$. The hottest period ranges from March to April with a mean temperature of 37 degrees Celsius. The population is comprised of Dagara and Bwaba (native) and Lobi and Mossi (migrant). Livelihood activities in the study area are diverse and often complementary, but rain-fed agriculture remains the dominant activity. Thus, the area is commonly known as the breadbasket of the country (Sanfo et al., 2014). In addition, local beer "dolo" selling is an important activity run by the women. In addition, seasonal migration is used to embed household needs in the study area.

\section{Figure 1: Map showing the study area}

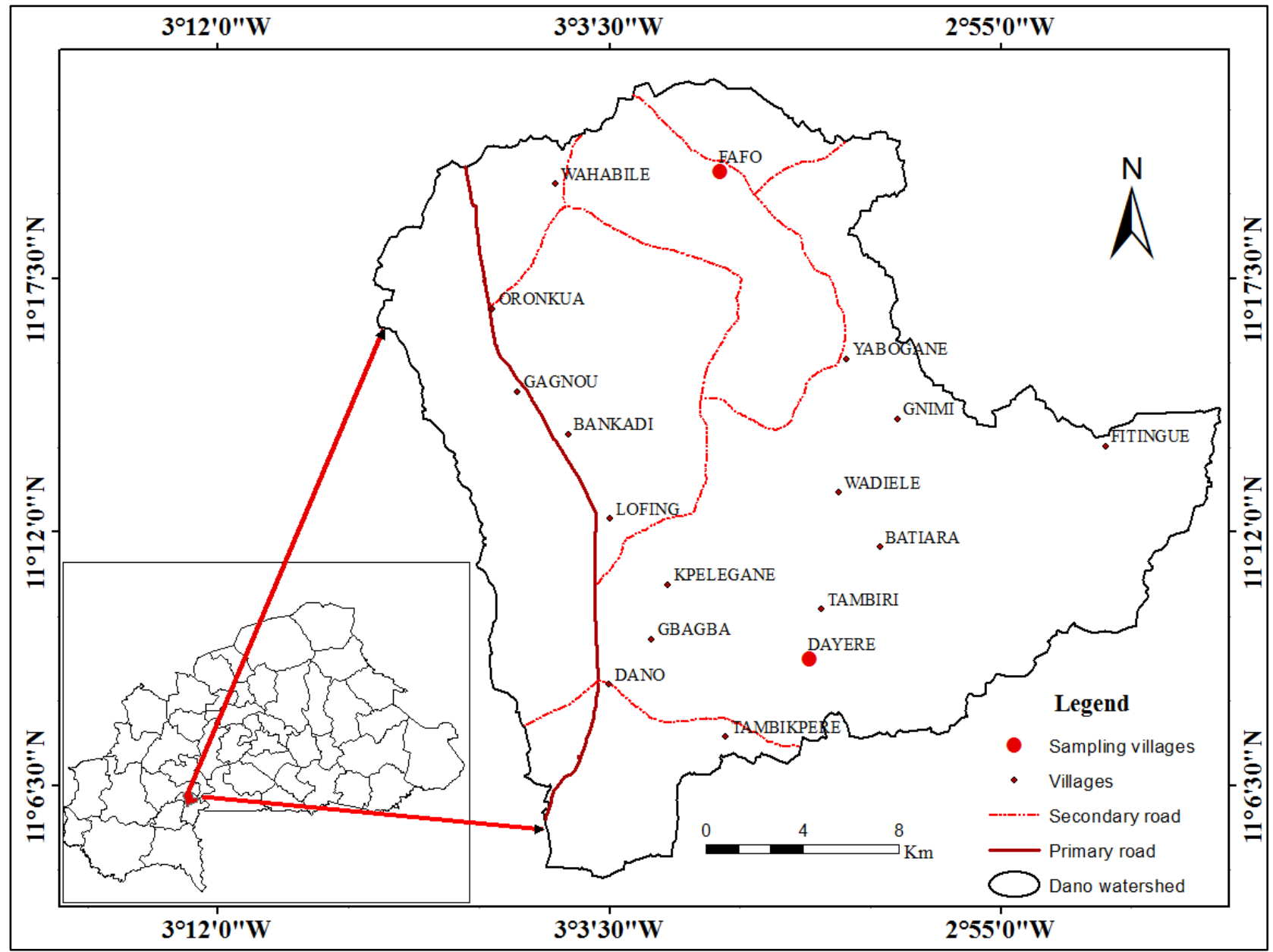

\section{Dataset}

The study used data collected through three separate focus group discussions (men, women and young men) followed by an interview conducted in the two villages; the interviewees were randomly selected and was confined to people aged $\geq 18$ years. Reports from the national population censuses do not provide data at the village level. The census data were collected from the town hall of Dano, Koti and Orankua. 2006 census data were reviewed to estimate the current population by using the following equation

$$
P_{(x)}=P_{(0)} \times(1+r \%)^{N}
$$

Where $\mathrm{P}_{(\mathrm{x})}$ is the population projection for year $\mathrm{x}, \mathrm{P}$ (0) is the population at the beginning (base), $\boldsymbol{r}$ is the growth rate, and $\mathrm{N}$ is the number of years.

81 This work is licensed under a Creative Commons Attribution 4.0 International License. 


\section{Satellite Data Acquisition Procedure}

Remote sensing techniques were used to provide a land cover map to derive vegetation cover characteristics as input parameters for land cover type. A total of three scenes of Landsat images Landsat Thematic Mapper (TM), Enhanced Thematic Mapper Plus (ETM+) and Operational
Land Imager (L8-OLI), were used for land cover classification. These free data with $30 \mathrm{~m}$ spatial resolution were available for the years 1986, 1999 and 2014 respectively and downloaded from the United States Geological Survey (USGS) website (http://glovis.usgs.gov). The characteristics of these images are shown in Table 1.

Table 1: Characteristics of the satellite images (TM, ETM+ and OLI)

\begin{tabular}{lllll}
\hline Satellite & Sensor & Scene reference & Spatial resolution & Acquisition date \\
\hline \multirow{3}{*}{ Landsat } & TM & path196; raw 052 & $30 \mathrm{~m}$ & 08 Oct 1986 \\
& ETM+ & path196; raw 052 & $30 \mathrm{~m}$ & 08 Oct 1999 \\
& Landsat 8-OLI & path196; raw 052 & $30 \mathrm{~m}$ & 21 Oct 2014 \\
\hline
\end{tabular}

\section{Data Analysis}

Computing the change in LULC and its relationship with population

The acquired images were geometrically corrected using a polynomial $1^{\text {st }}$ order and classified using the supervised maximum likelihood method (Mas et al., 2004, Rawat and Kumar 2015, Traore et al., 2014, Traore et al., 2015, Ouedraogo et al., 2010). This method is one of the most popular for satellite image classification and also, it is based on the probability that a pixel belongs to a particular class. The rate of land conversion between periods was computed using the "from-to" function (Mas et al., 2004), and a cross-tabulation matrix was produced. Once the areas of LULC types were obtained for each period, the following equation was employed to calculate the rate of change (r).

$$
r=1-\left(1-\frac{A_{1}-A_{2}}{A 1}\right)^{\frac{1}{t}}
$$

where $A_{1}$ is the area covered by a given LULC at time $1, A_{2}$ the area at time 2 and $t$ is the number of years for the period of analysis.

After the computation of the extend of each LULC type, a Pearson correlation analysis were used to find the relationship between the total population and the land cover types such as vegetation and cropland. Thus. Data from the census and interview were analysed by using descriptive statistics.

\section{RESULTS AND DISCUSSION}

\section{Land Use and Land Cover Change Detection}

Five (5) LULC classes (i) Bare-land, (ii) Cropland, (iii) Dense Vegetation, (iv) Low Vegetation and (v) Water Bodies were identified and mapped. The result of the analysis (Table 2) shows that the most dominant LULC class in 1986 was low vegetation which occupied $24,843.96$ ha $(43 \%$ of the catchment). This was followed by the cropland with $18,828.51$ ha $(32 \%)$, dense vegetation with $12,990.18$ ha $(22 \%)$, bare-land with $14,80.75$ ha $(3 \%)$ and water bodies with 99.04 ha $(0.1 \%)$. The order of magnitude and the spatial extent of the LULC classes in 1999 and 2014 were different from 1986. In 1999, the most dominant LULC classes were dense vegetation, about $19,310.75$ ha $(33 \%)$ and cropland with about $19,185.82 \mathrm{ha}(33 \%)$. These were followed by low vegetation of $18,469.40$ ha $(32 \%)$; bare-land of $1,080.75$ ha $(2 \%)$ and water bodies of 195.77 ha $(0.3 \%)$. Increased water body area is a result of water conservation management after the second drought in the 1980s, this in order to facilitate farming during the dry season through irrigation. However, in 2014 about 1\% of the catchment (338.74 ha) was burnt with bush fires. It can be well observed in 2014, there was an increase of cropland for about $34 \%(20,073.61)$, while a decrease occurred in the areas of dense vegetation for about $26 \%(15,315.67)$ and low vegetation for about $30 \%(17,222.81)$ compared to its coverage in 1999. In addition, the area of bare land was also intensified as the population increased. 
East African Journal of Environment and Natural Resources, Volume 4, Issue 1, 2021

Article DOI: https://doi.org/10.37284/eajenr.4.1.517

Table 2: Total area of land cover types in 1986, 1999 and 2014

\begin{tabular}{lllllll}
\hline LULC Classes & $\begin{array}{l}\mathbf{1 9 8 6} \\
\text { Total } \\
\text { (ha) }\end{array}$ & \% & $\begin{array}{l}\text { 1999 } \\
\text { Total } \\
\text { (ha) }\end{array}$ & \% & $\begin{array}{l}\mathbf{2 0 1 4} \\
\text { Total } \\
\text { (ha) }\end{array}$ & \% \\
\hline Bare-land & $1,480.75$ & 3 & $1,080.75$ & 2 & $5,153.46$ & 9 \\
Cropland & $18,828.51$ & 32 & $19,185.82$ & 33 & $20,073.61$ & 34 \\
Dense Vegetation & $12,990.18$ & 22 & $19,310.75$ & 33 & $15,315.67$ & 26 \\
Low Vegetation & $24,843.96$ & 43 & $18,469.40$ & 32 & $17,222.81$ & 30 \\
Water Bodies & 99.04 & 0.2 & 195.77 & 0.3 & 138.14 & 0.2 \\
Burned Area & 0 & 0 & 0 & 0 & 338.74 & 1 \\
\hline
\end{tabular}

During the analysis, the area of change has been observed during the study periods in each class (Table 3). Over the study periods, low vegetation lost 7,517.21 ha and decreased continuously up that is 1986 to 2014 , which was contrary to cropland with an annual rate of increase of $0.93 \%$. From 1986 to 1999 , a negative change was recorded in the areas of low vegetation (6,374.5 ha) and bare-land (-400 ha). From 1999 to 2014, a decrease was more notable in the dense vegetation $(-3,995.08 \mathrm{ha})$, low vegetation (-1,142.68 ha) and water bodies (-57.63 ha); this could be explained by the increase of frequent rainfall anomalies and increased demand for natural resources. The observed changes of LULC in the study area were characterised by a decrease in low vegetation (mixed vegetation and woodland). The ongoing process of deforestation, road and settlement building could explain by the conversion of natural vegetation.

Table 3: Statistic of land cover change

\begin{tabular}{llll}
\hline LULC Classes & \multicolumn{2}{c}{ Area of change (ha) } & 1986-2014 \\
\cline { 2 - 3 } & $\mathbf{1 9 8 6 - 1 9 9 9}$ & $\mathbf{1 9 9 9 - 2 0 1 4}$ & \\
\hline Bare land & -400 & 4072.71 & 3672.71 \\
Cropland & 357.31 & 1235.75 & 1593.06 \\
Dense Vegetation & 6320.57 & -3995.08 & 2325.49 \\
Low Vegetation & -6374.5 & -1142.68 & -7517.21 \\
Water Bodies & 96.73 & -57.63 & 39.10 \\
\hline
\end{tabular}

\section{Relationship between LUCC Change and Population density}

The Dano watershed, like other parts of the country, has known a rapid population growth over the two (2) last censuses. The population density had shifted from 91 habitant $/ \mathrm{km}^{2}$ in 2006 to 118 habitants / $\mathrm{km}^{2}$ in 2014. However, the population density in the Ioba province is among the highest in Burkina Faso (Gleisberg-Gerber, 2012). The Pearson correlation confirmed a negative correlation $(r=0.96)$ between the area of vegetation and population. This means that population growth impacts negatively upon vegetation cover. Result from Pearson is highly supported by the survey result $68 \%$ of farmers do not have available land. On the second hand, the result from the Pearson correlation also confirmed a strong positive correlation $(r=0.99)$ between cropland and population size. Over the study period, the annual rate of increase in the area of cropland was $0.92 \%$. Population growth increases pressure on agricultural land although significant fertility declines always happen in the study area. This is asserted when the farmers confirmed that they add a new portion of land to their farms each year, mostly driven by demand for food. The population in the study area shipped from 52936 inhabitants in 2006 to 68817 inhabitants in the year 2014 Meanwhile, the respondents especially, young men and women linked early marriage to rapid population growth. For example, eighteen years old girls are mothers of at least two children. Similar to (Ouedraogo, 2010; Traore et al., 2014), demographic factors seem to be important drivers in both agricultural intensification and fuelwood use. Also, the implementation of new farming 
techniques together with the increasing demand for food to feed the growing population, may have contributed to important ecosystem degradation in Burkina Faso.

An expansion of annual crop areas at the expense of savannah and forest is highlighted in the literature as a primary effect of the introduction of cotton (Gleisberg-Gerber, 2012). Households that are strongly involved in cash crops production (cotton and maise) are the most exposed to the risk of soil degradation through the application of chemical fertilisers, even though they have the highest total annual income.

The overall result of LULC demonstrated a tendency for environmental degradation in the study area. This finding is highly supported by survey data; the majority $(78 \%)$ of the respondents mentioned deforestation as the major driver of environmental change in the Dano watershed.
However, the cutting down of trees for firewood and cropland expansion is very common (Bilsborrow, 2002). The area has also experienced several rainfall anomalies which in turn have impacted negatively the life cycle of ecosystems and the loss of some species of wildlife and plants. The explanation, following Malthus and Boserup, a country with high population growth will be stimulated to have greater expansions in their agricultural land area. In other words, the conversion of forest land to cropland often means an abrupt change in biomass (Vliet et al., 2013). And also, charcoal production, bushfire and mining have contributed to deforestation in the study area (Zoungrana et al., 2015), [interviewees]. LULC changes are closely interconnected in multiple and bi-directional ways to changes in local livelihoods and the provision of ecosystem services. LULC changes related to environmental degradation and change have been changing for the worse on rural livelihood.

Figure 2: Correlation between the area of cropland, vegetation and population

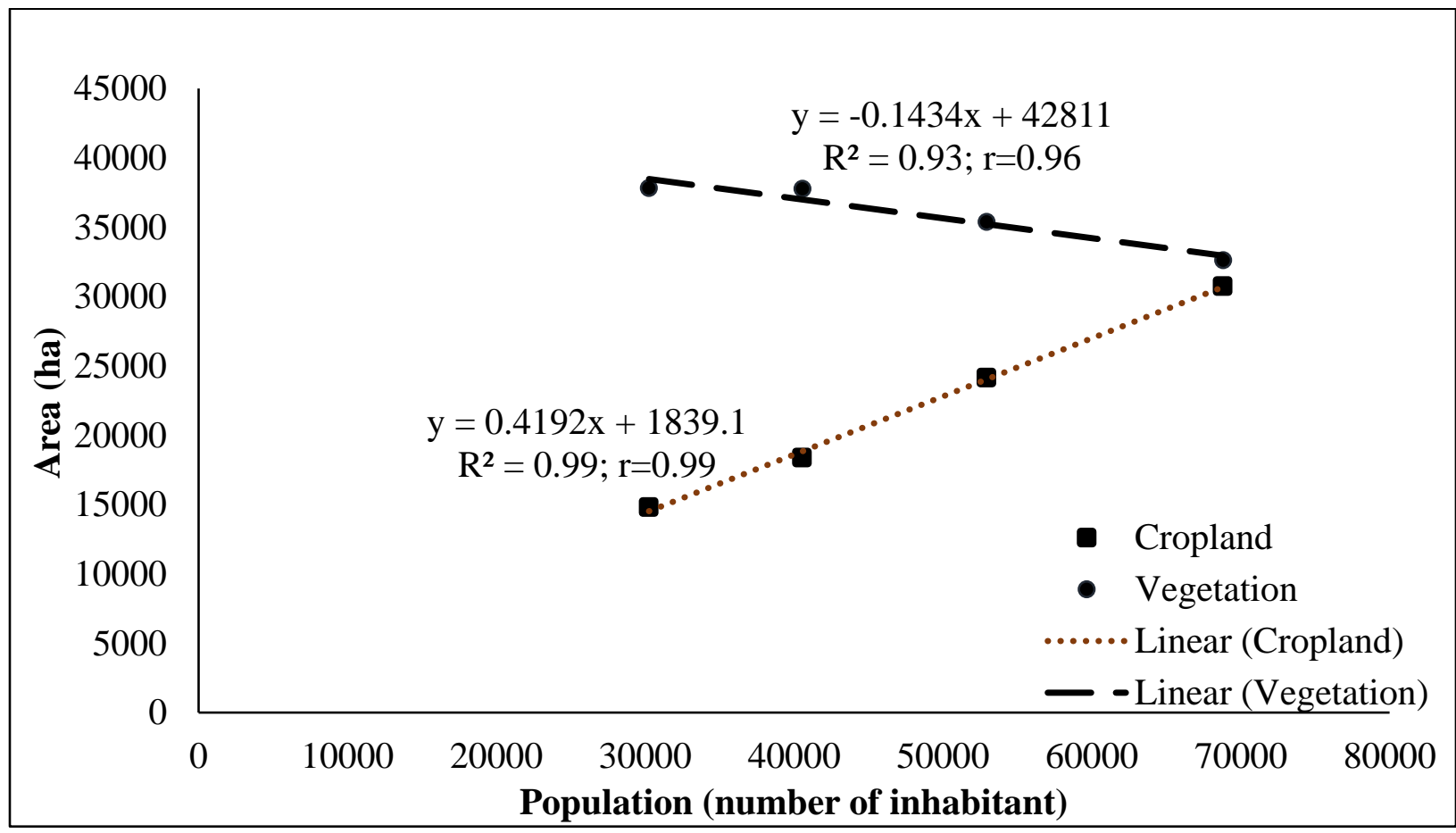

Farmers have linked environmental change as a threat to their livelihood security. They identified two (2) pillars of human security (food and health security) which are now affected. The farmers perceived that the existing impacts of environmental change resulted in crop and livestock production failure. However, the majority of the respondents (71\%) find a direct link between the decrease in rainfall and the economic situation of the household. Long dry spells during critical stages in the planting season seriously influence crop production, leading to reduced yields. Sorghum and cotton were also 
identified as being more vulnerable, among other crops. The overall situation results to undermine the availability and quality of food and forage for livestock. It was noted that when crop yield fails, that influences the price for that particular crop which increases as a result of high demand and low supply. For instance, the price of sorghum and maise increases the very month it is harvested, and it will keep going up until the new harvest.

\section{Adaptation and Coping Strategies to LULC Change in the Study Area}

Adaptation strategies remain a big challenge for the farmers since the phenomenon is unpredictable (chief of Fafo village). Even though the village is lucky to have projects and NGOs working in the context of capacity building, but they are still suffering from soil degradation. The projects "Programme de Développement Agricole" (PDA) and "Office de Développement des Evangéliques" (ODE) have ranged of complementary practices to improve soil. Some cropland areas have been restored to productivity using manual techniques such as planting pits (zai), half-moons, stone lines and stone bunds. Besides, the use of compost pits, natural phosphates and agroforestry techniques further strengthen resilience to the impact of environmental change. In addition, the "Société Burkinabé des Fibres et Textiles" (Sofitex) makes easy the availability and accessibility of the agricultural input to enhance cotton and maise production.

\section{Table 4: Response strategies to environmental change in the study area}

\begin{tabular}{ll}
\hline Coping and Adaptation strategies & Answers (\%) \\
\hline Stone bund & 3 \\
Activity diversification & 16 \\
Migration & 31 \\
Traditional method & 1 \\
Earth Basin & 2 \\
Use of entrants & 17 \\
Early crop & 31 \\
\hline
\end{tabular}

\section{Migration as Response Strategy in the Study Area}

Famers have developed several coping and adaptation strategies to ensure household security. Among the strategies, migration has been classified as a crucial strategy to diversify household income. It is well documented by several studies that migration has always been a local response or survival strategy of people confronted by environmental changes that endanger human welfare (Renaud et al., 2007, IOM, 2008, Ouedraogo et al., 2010, Warner, 2011, Sow et al., 2014). Migration in the study area is not a new phenomenon, it is part of the tradition. In fact, due to social and cultural norms, male migration is more common than female migration. About $62 \%$ of households had at least one migrant.

\section{Benefits and Life Improvement from Migration}

At the household level, migration has improved living conditions in many households in the study area. The benefits stated by the migrants and their relatives were the following: family needs $(44 \%)$, saving (41\%), purchase of motorbike $(5 \%)$, the building of houses (4\%), agricultural input (4\%) and procurement of knowledge (1\%). The income from migration is on family needs; these include school fees for the kids, health care and other unexpected events. Additionally, migrants and their family members claim that the income from the migration guaranteed food security in their households. Migrant households benefit more from the village endowment in millet lands because they can invest in their agricultural plots to enhance productivity. Poverty reduction 38\%, improvement of living standards $(27 \%)$, the building of modern houses $(13 \%)$, transport accessibility or facility (12\%), the immigrants invest in the village $(7 \%)$ and the establishment of workshops in the village (3.2\%). However, some interviewees consider migration itself as "a school of life," "once we left our village, we interact with many people, we learned from

85 This work is licensed under a Creative Commons Attribution 4.0 International License. 
them, and gathered the experiences and learned their language" [Interviewees].

\section{CONCLUSION}

The work demonstrates the linkage between environmental change and human mobility using the case study of the Dano watershed area in Ioba province, south-western Burkina Faso. Results from the present study disclosed a substantial land cover change in the Dano watershed. Increased demand for natural resources (cropland and firewood), mostly driven by rapid population growth, is subject to high LULC dynamics and change in the study area. Environmental change was shown to be one of the drivers of migration that will continue to influence the farmers thought even to discourage the young generation from abandoning agriculture. Households in the Dano watershed have coped with environmental by changing their agricultural practices (soil conservation, early mature crop etc.) and diversifying their livelihoods make them less dependent on rain-fed agriculture. Indeed, policy decisions regarding environmental change and rural migration and long-term climatic risk must be taken into account in future analysis.

\section{ACKNOWLEDGEMENT}

We would like to thank the German Federal Ministry of Education and Research (BMBF) which fully funded this research through West African Science Service Center on Climate Change and Adapted Land Use (WASCAL).

\section{REFERENCES}

Abdul-Korah, G. B. (2008). 'Ka Bie Ba Yor': labor migration among the Dagaaba of the Upper West Region of Ghana, 1936-1957. Nordic Journal of African Studies, 17(1), 1-19.

Abroulaye, S., Issa, S., Abalo, K. E., \& Nouhoun, Z. (2015). Climate change: a driver of crop farmersagro pastoralists conflicts in Burkina Faso. International journal of applied science and technology, 5(3).

Bilsborrow, R. E. (2002). Migration, population change, and the rural environment. Environmen tal change and security project Report, 8(1), 6984.
Gleisberg-Gerber, K. (2012). Livelihoods and land management in the Ioba Province in southwestern Burkina Faso (No. 91). ZEF Working Paper Series.

International Fund for Agricultural Development (IFAD). (2011). New Realities, New Challenges: New Opportunities for Tomorrow'S Generation. IFAD

Iom International Organization for Migration (IOM). (2008). Migration, development and poverty reduction in Asia. Academic Foundation. Iom International Organization for Migration. (2008). Migration, development and poverty reduction in Asia. Academic Foundation.

Mas, J. F., Velázquez, A., Díaz-Gallegos, J. R., Mayorga-Saucedo, R., Alcántara, C., Bocco, G. \& Pérez-Vega, A. (2004). Assessing land use/cover changes: a nationwide multidate spatial database for Mexico. International Journal of Applied Earth Observation and Geoinformation, 5(4), 249-261.

Masih, I., Maskey, S., Mussá, F. E. F., \& Trambauer, P. (2014). A review of droughts on the African continent: a geospatial and long-term perspective. Hydrology and Earth System Sciences, 18(9), 3635-3649.

Ouedraogo, I. (2010). Land use dynamics and demographic change in Southern Burkina Faso (Vol. 2010, No. 2010: 63).

Ouedraogo, I., Ouattara, K., Kaboré, S., Sawadogo, S. P., \& Barron, J. (2012). Permanent internal migration as response to food shortage: implication to ecosystem services in southern Burkina Faso. Food production: Approaches, challenges and tasks, 41-54.

Ouedraogo, I., Savadogo, P., Tigabu, M., Cole, R., Odén, P. C., \& Ouadba, J. M. (2009). Is rural migration a threat to environmental sustainability in Southern Burkina Faso? Land degradation \& development, 20(2), 217-230.

Ouedraogo, I., Tigabu, M., Savadogo, P., Compaoré, H., Odén, P. C., \& Ouadba, J. M. (2010). Land cover change and its relation with

86 This work is licensed under a Creative Commons Attribution 4.0 International License. 
population dynamics in Burkina Faso, West Africa. Land Degradation \& Development, 21 ( 5), 453-462.

Rawat, J. S., \& Kumar, M. (2015). Monitoring land use/cover change using remote sensing and GIS techniques: A case study of Hawalbagh block, district Almora, Uttarakhand, India. The Egyptian Journal of Remote Sensing and Space Science, 18(1), 77-84.

Renaud, F. G., Bogardi, J. J., Dun, O., \& Warner, K. (2007). Control, adapt or flee: How to face environmental migration? UNU-EHS.

Sanfo, S., Lamers, J., Mueller, M., \& Fonta, W. (2014). Farmers' Perception of climate change and climate variability versus climatic evidence in Burkina Faso, West Africa. Proceedings of the Climate Change in Africa. Negotiations, Translations, and Socio-Political Implications, Bonn, Germany, 10-12.

Sow, P., Adaawen, S. A., \& Scheffran, J. (2014). Migration, social demands and environmental change amongst the Frafra of Northern Ghana and the Biali in Northern Benin. Sustainability, 6(1), 375-398.

Traore, S. S., Forkue, E. K., Traore, P. C., \& Landmann, T. (2015). Assessing the interrelationship between vegetation productivity, rainfall, population and land cover over the Bani River Basin in Mali (West Africa). IOSR Journal of Engineering, 5(6), 10-18.

Traore, S. S., Landmann, T., Forkuo, E. K., \& Traore, P. C. S. (2014). Assessing long-term trends in vegetation productivity change over the Bani River Basin in Mali (West Africa). Journal of Geography and Earth Sciences, 2(2).

Van der Geest, K., Vrieling, A., \& Dietz, T. (2010). Migration and environment in Ghana: a crossdistrict analysis of human mobility and vegetation dynamics. Environment and Urbanisation, 22(1), 107-123.

van Vliet, N., Reenberg, A., \& Rasmussen, L. V. (2013). Scientific documentation of crop land changes in the Sahel: A half empty box of knowledge to support policy? Journal of Arid Environments, 95, 1-13.

Warner, K. (2011). Environmental change and migration: methodological considerations from ground-breaking global survey. Population and environment, 33(1), 3-27.

Zoungrana, B. J., Conrad, C., Amekudzi, L. K., Thiel, M., Da, E. D., Forkuor, G., \& Löw, F. (2015). Multi-temporal landsat images and ancillary data for land use/cover change (LULCC) detection in the Southwest of Burkina Faso, West Africa. Remote Sensing, 7(9), 12076-12102. 